\title{
U-Pb Geochronology of the Jebba Granitic Gneiss and Its Implications for the Paleoproterozoic Evolution of Jebba Area, Southwestern Nigeria
}

\author{
C. T. Okonkwo ${ }^{1}$, V. Y. Ganev ${ }^{2}$ \\ ${ }^{1}$ Department of Applied Geology, Federal University of Technology, Akure, Nigeria \\ ${ }^{2}$ Institute of Mineralogy and Crystallography, Bulgarian Academy of Sciences, Sofia, Bulgaria \\ Email: ctoo2003@yahoo.com
}

Received July 10, 2012; revised August 22, 2012; accepted September 21, 2012

\begin{abstract}
Jebba area southwestern Nigeria forms part of the Nigerian basement complex which lies in the Neoproterozoic PanAfrican mobile belt. It is underlain by several lithological units among which is a polydeformed granitic gneiss. This rock has been dated by LA-ICP-MS yielding a concordant U-Pb zircon age of $2207 \pm 20$ Ma indicating the crystallization age of the granite protolith. This early Rhyacian age and its affinity with within-plate granites indicates emplacement during crustal extension and rifting preceding the main phase of the Eburnean orogeny. The strong, early, shear fabric, $\mathrm{S}_{1}$, in the rock is interpreted to be also of Paleoproterozoic age i.e. imprinted during the Eburnean orogeny. The Jebba granitic gneiss is thus correlatable with the widely abundant Paleoproterozoic granitic magmatism now represented by many orthogneisses and documented in other parts of southwestern Nigeria, the West African craton, the Borborema Province, the Gurupi Belt, Sao Luis craton and Sao Francisco craton in Brazil.
\end{abstract}

Keywords: Jebba Area Nigeria; Granitic Gneiss; U-Pb Dating; Paleoproterozoic; Eburnean Orogeny

\section{Introduction}

The Nigerian basement complex forms the southern part of the Trans-Saharan Pan-African mobile belt [1] of Neoproterozoic (500 - $750 \mathrm{Ma})$ age situated between the Archean-Paleoproterozoic blocks of the West African craton to the west, the East Saharan block to the east and the Congo craton to the southeast (Figure 1). This basement complex comprises gneisses, migmatites and supracrustals which have yielded Archean and Proterozoic ages [2,3] and bears the imprints of Liberian ( $c$ a 2700 Ma), Eburnean ( ca $2000 \mathrm{Ma}$ ) and Pan-African ( ca 600 $\mathrm{Ma}$ ) orogenic events [3-9]. The polyphasal nature of the deformation and metamorphism of the Nigerian basement complex rocks has been recognized and documented by several workers e.g. [7,10-13]. Several orthogneisses of Paleoproterozoic age have been documented from some parts of southwestern Nigeria including Ibadan granitic gneiss- $\mathrm{Rb} / \mathrm{Sr}$ isochron age of $2206 \pm 70 \mathrm{Ma}$ [4], Ile-Ife grey gneiss-U-Pb age of $2.3 \mathrm{Ga}$ [9], Igbeti augen gneiss- $\mathrm{Rb} / \mathrm{Sr}$ isochron age of $1.9 \mathrm{Ga}$ [14], Kabba granodioritic gneiss-U-Pb age of $2103 \pm 8 \mathrm{Ma}$ [2].

However, in Jebba area, lack of geochronological data has not allowed the different rock suites related to the different orogenic cycles to be distinguished. In particular, the age relations of the various rock units in the area were not known and it was not possible to constrain the lithotectonic evolution of the area on a geochronogical basis. Of critical importance are the age relations of the several generations of granitic rocks showing a wide range in terms of tectonic deformation and development of structural fabrics that are exposed in the area. In particular, the ages of the strongly foliated and folded granitic orthogneisses and their stratigraphic position in relation to the other rock units and to the recognised orogenic events affecting the Nigerian basement complex has been unclear.

This paper reports the first data on the geochronology of the leucocratic Jebba granitic gneiss, a very strongly deformed and folded unit in the area and examines its significance in the Paleoproterozoic crustal evolution of the area and also discusses it correlation with other parts of the Nigeria basement complex and western Gondwana, especially Brazil.

\section{Geology of Jebba Area}

Jebba area lies at the northern margin of the southwestern sector of the Nigerian basement complex (Figure 2). The area is underlain by metasedimentary and metaigneous rocks which have undergone polyphase deformation and metamorphism in the range of greenschist to amphibolite 


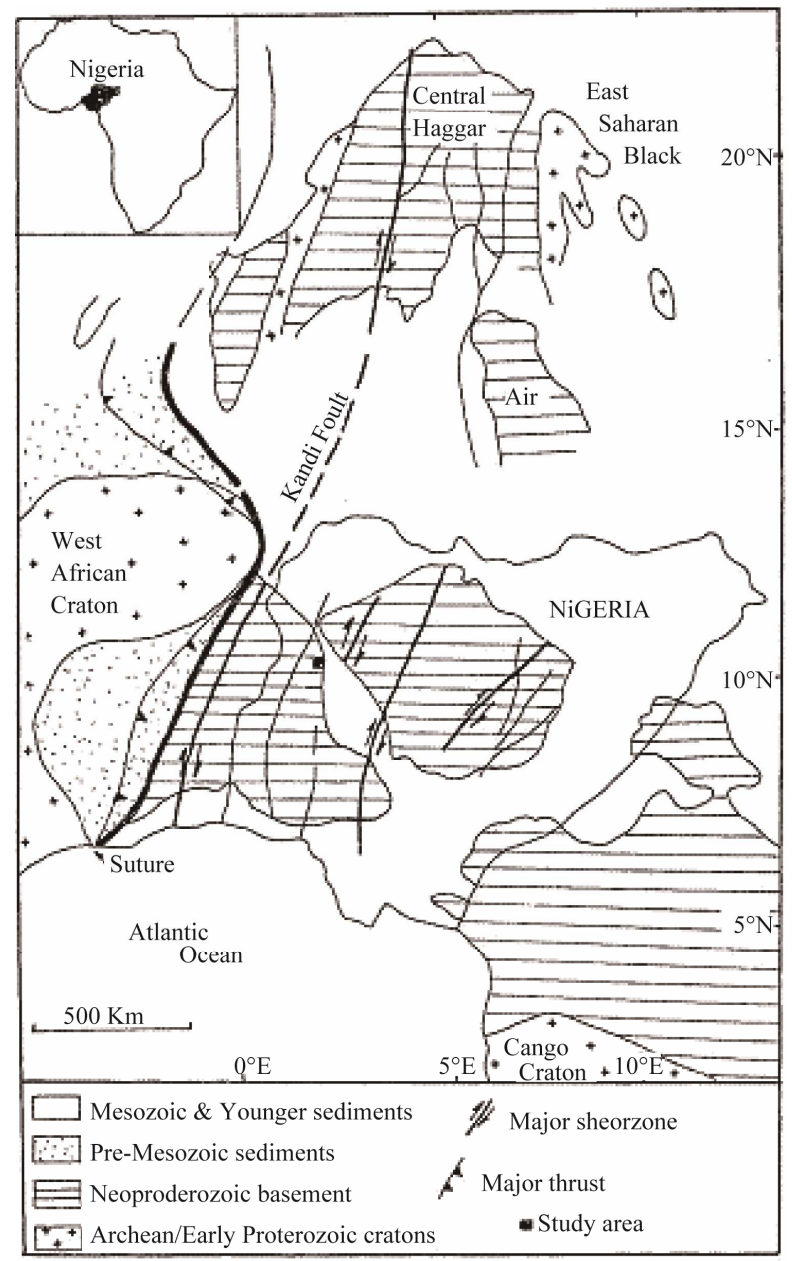

Figure 1. Index map showing the location of Jebba area, Nigeria within the Neoproterozoic trans-saharan mobile belt (after Ferre et al., 2002).

facies [13]. These rocks have been intruded by largely undeformed granitic rocks of probable Neo-Proterozoic age emplaced during the Pan-African orogeny. Four lithostratigraphic units have been recognized in Jebba area (Figure 2). In the east is an N-S trending belt of quartzofeldspathic gneiss with local quartzofeldspathic veining which contains a thick, intercalated quartzite. This gneiss is bounded on the west by an N-S belt of granitic gneiss. West of this is a metagreywacke unit with intercalated amphibolites bands, to the west of this is a very thick sequence of quartzites which locally contain preserved cross-stratification. The western and eastern bodies of quartzite are locally pebbly. Quartz mica schists occur in the far west. These metamorphic rocks have been intruded by largely undeformed granitic rocks ranging from porphyritic to medium-grained varieties.

Five phases of deformation have recognized in the metamorphic rocks of the area. These involved foliation development, several generations of folding as well as ductile shearing and brittle faulting [13]. The boundary between the granitic gneiss and the metagreywacke is a tectonic one defining a ductile thrust with a top to the southeast transport direction [13].

This paper reports geochronological data on this granitic gneiss and assesses their implications for the tectonic evolution of Jebba area.

\section{Petrography of the Jebba Leucocratic Granitic Gneiss}

This is a leucocratic, medium-grained strongly foliated and lineated rock containing plagioclase $(40 \%)$, quartz $(25 \%)$, microcline (18\%), muscovite $(15 \%)$ and a few biotite grains. Muscovite forms overgrowths on muscovite as well as on the opaque mineral suggesting some replacement of biotite by muscovite accompanied by the release of the ore mineral. Accessory minerals are magnetite, apatite, titanite, zircon, chlorite, sericite and epidote. The very strong planar fabric is defined by the alignment of muscovite and quartz ribbons as well as by opaque mineral (magnetite) strewn along the foliation.

The granitic gneiss is also locally marked by also a very strong linear fabric — a stretching lineation — defined by quartz and feldspar grains plunging gently to the NNW [13]. Locally, the granitic gneiss contains very thin, elongate slivers (xenoliths) of dark, schistose material believed to be derived from the preexisting country rock.

\section{Geochemistry of the Granitic Gneiss}

The chemical compositions of seven samples of the granitic gneiss obtained by X-Ray Fluorescence spectrometry are presented in Table 1. Analytical methods and precision are as described by [15].

\subsection{Major Elements}

The rock classifies as a granite on the classification diagram of [16] (Figure 3(a)). It is a highly siliceous rock with $\mathrm{SiO}_{2}$ contents higher than $75 \%$. Total iron as $\mathrm{Fe}_{2} \mathrm{O}_{3}$ contents range from $2.53 \%$ to $3.06 \%$. $\mathrm{MgO}$ and $\mathrm{CaO}$ contents are very low, less than $0.20 \%$, and $1 \%$, respectively. On the $\mathrm{K}_{2} \mathrm{O}$ versus $\mathrm{SiO}_{2}$ plot after [17] it plots as a high-K calc-alkaline granite (Figure 3(b)) and in the calc-alkaline field in the AFM triangular diagram (Figure 4(a)). The granitic gneiss is slightly peraluminous in the molecular $\mathrm{Al}_{2} \mathrm{O}_{3} / \mathrm{CaO}+\mathrm{NaO}+\mathrm{K}_{2} \mathrm{O}$ versus $\mathrm{SiO}_{2}$ diagram (Figure 4(b)) and ferroan (Figure 4(c)) in the $\mathrm{Fe}_{2} \mathrm{O}_{3} \mathrm{t} / \mathrm{Fe}_{2} \mathrm{O}_{3} \mathrm{t}+\mathrm{MgO}$ ) versus $\mathrm{SiO}_{2}$ diagram of [18].

\subsection{Trace Elements and Tectonic Classification}

The rock contains appreciably higher concentrations of the high field strength elements e.g. $\mathrm{Zr}, \mathrm{Nb}$ and $\mathrm{Y}$ and the heavy rare-earth elements e.g. $\mathrm{La} \mathrm{Ce}$ and $\mathrm{Nd}$. On the $\mathrm{Nb}$ versus $\mathrm{Y}$ tectonic setting discrimination diagram after [19] 


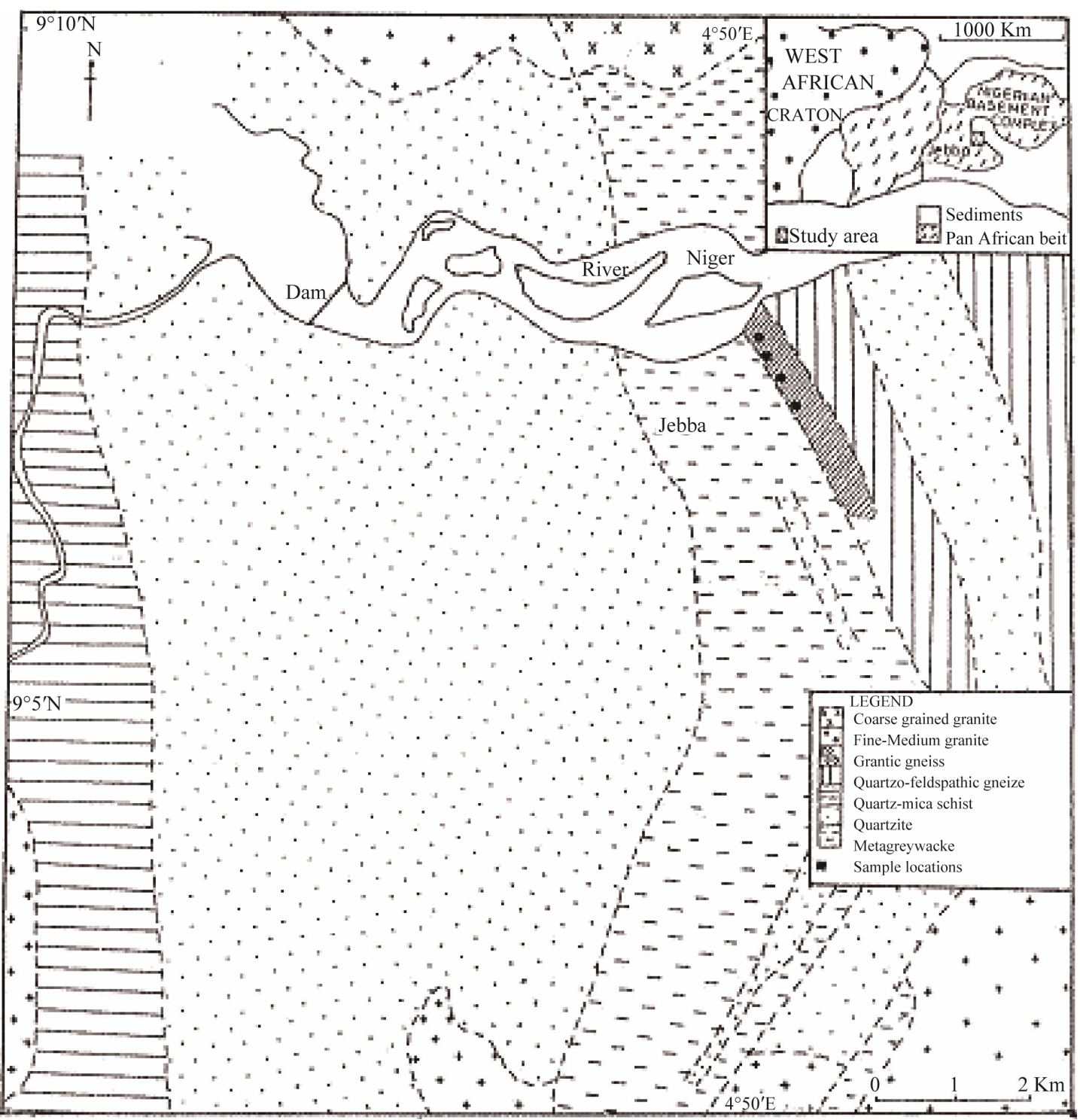

Figure 2. Geological map of Jebba area.

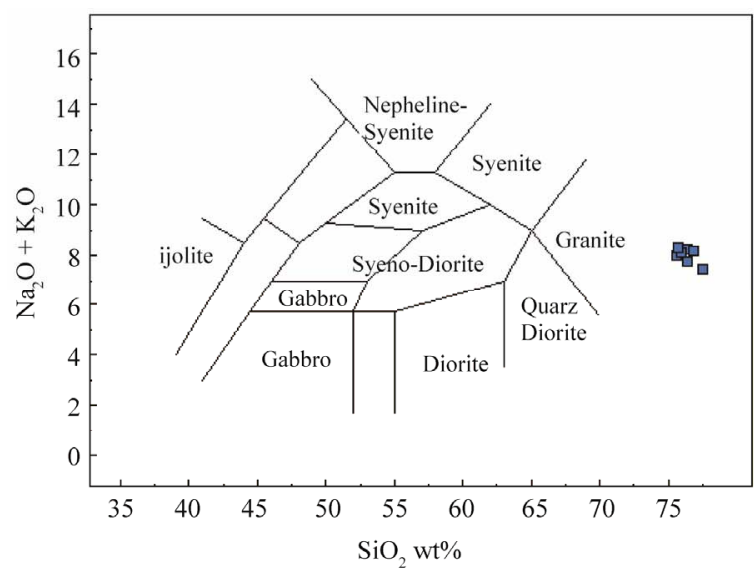

(a)

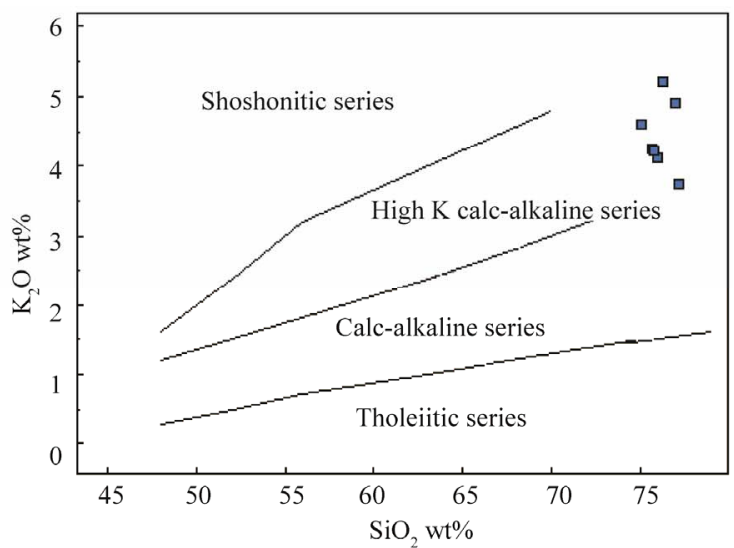

(b)

Figure 3. (a) Chemical classification of the rocks after cox et al. (1979); (b) Classification of the granitic gneiss after peccerrillo and taylor (1976). 


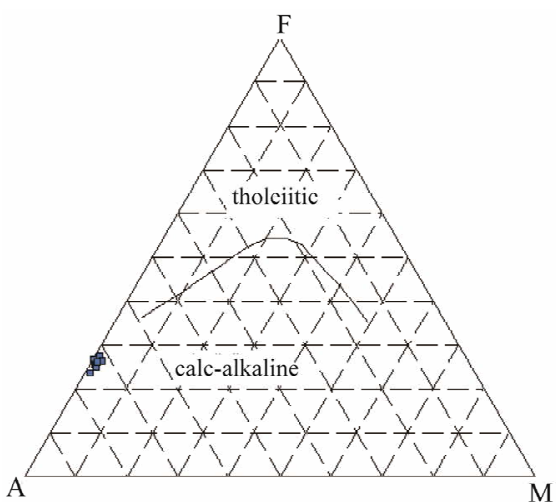

(a)

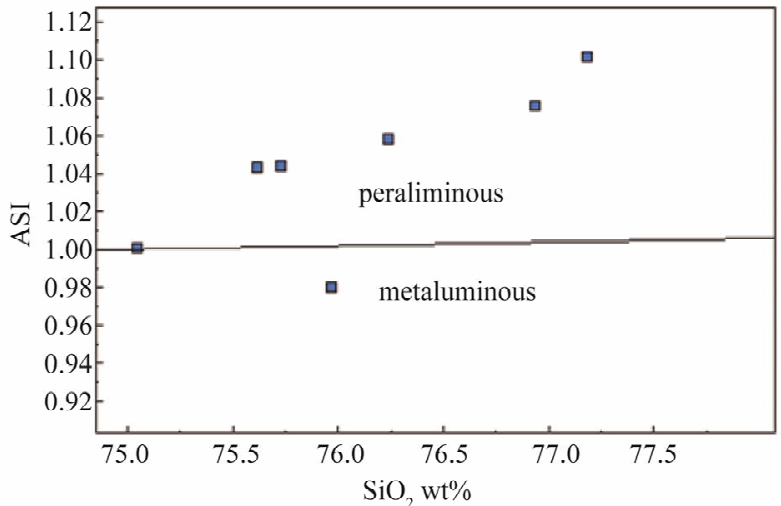

(b)

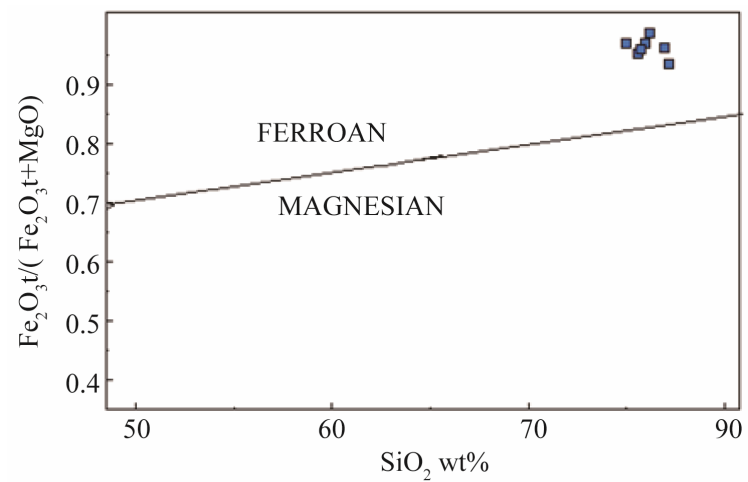

(c)

Figure 4. (a) AFM diagram shwoing the calc-alkaline classification of the gneiss; (b) ASI versus $\mathrm{SiO}_{2}$ plot indicating the peraluminus character of the rock; (c) $\mathrm{Fe}_{2} \mathrm{O}_{3} \mathrm{t} /\left(\mathrm{Fe}_{2} \mathrm{O}_{3} \mathrm{t}+\mathrm{MgO}\right)$ versus $\mathrm{SiO}_{2}$ plot shwwing the ferroan nature of the gneiss after Frost et al. (2001).

(Figure 5(a)) the granitic gneiss plots in the within-plate field. This is also supported by the plot of the rock in the $\mathrm{Rb}$ versus $\mathrm{Nb}+\mathrm{Y}$ diagram (Figure 5(b)).

Thin sheets of amphibolite intercalated with the metagreywacke in the area also have chemical characteristics of within-plate basalts [20] suggesting that they were emplaced in an extensional tectonic environment. The protoliths of the granitic gneiss and the amphibolite were therefore products of bimodal magmatism associated with intracontinental rifting [20].

\section{Zircon Morphology and Internal Features}

Zircon grains from the granitic gneiss are largely squatshaped with one end broken and are characterized by fractures (Figure 6, BSE image). The grains also exhibit well-developed oscillatory (concentric) growth zoning (Figure 6, CL image) indicative of originally igneous zircons [21]. The obtained average $\mathrm{Th} / \mathrm{U}$ ratio $(0.54)$ is also typical of zircons formed by igneous processes.

\section{Geochronology}

Zircons from this rock were analyzed by LA-ICP-MS technique in the Institute of Mineralogy and Crystallog- raphy of Bulgarian Academy of Sciences, Sofia, Bulgaria using a PerkinElmer ELAN DRC-e ICP-MS connected to the NWR/ESI UP-193FX ArF excimer laser ablation system. A cathodoluminescence (CL) and back-scattered electron (BSE) imaging of each selected zircon grain previously mounted in epoxy and finely polished were performed prior to the mass spectrometry measurements. The representative zircon selection was made from an initial sample set of more than 100 grains. All electron microscopy investigations were performed on the Zeiss EVO 25LS SEM. The main parameters of the LA-ICPMS instrument set-up are described in Table 2.

The machine was calibrated and optimized to the proper $\mathrm{U}-\mathrm{Pb}$ ratios at high signal sensitivity level by repeated measurements of GJ-1 natural zircon standard [22]. Another widely used LA-ICP-MS geochronology zircon reference material (Plesovice) was adopted for data verification purposes [23]. Each five sample unknowns were bracketed by two standard measurements both from GJ-1 and Plesovice performed under the same analytical conditions. The off-line data reduction code Iolite [24] was implemented for calculation and correction of the $\mathrm{U}-\mathrm{Pb}$ ratios before final age calculation procedure was performed by Isoplot toolkit [25]. The ob- 
Table 1. Chemical composition of Jebba granitic gneiss (major elements in wt\%, trace elements in ppm).

\begin{tabular}{|c|c|c|c|c|c|c|c|}
\hline & CT908 & СТ909 & CT921 & JBG4 & JBG5 & $909 \mathrm{~B}$ & 8802 \\
\hline $\mathrm{SiO}_{2}$ & 76.24 & 75.05 & 75.97 & 75.62 & 77.19 & 76.94 & 75.73 \\
\hline $\mathrm{TiO}_{2}$ & 0.28 & 0.28 & 0.27 & 0.35 & 0.28 & 0.28 & 0.27 \\
\hline $\mathrm{Al}_{2} \mathrm{O}_{3}$ & 11.65 & 11.88 & 11.69 & 12.14 & 11.48 & 11.82 & 12.19 \\
\hline $\mathrm{Fe}_{2} \mathrm{O}_{3} \mathrm{t}$ & 2.97 & 3.06 & 2.68 & 2.78 & 2.72 & 2.53 & 2.96 \\
\hline $\mathrm{MnO}$ & 0.00 & 0.02 & 0.04 & 0.03 & 0.02 & 0.02 & 0.03 \\
\hline $\mathrm{MgO}$ & 0.04 & 0.10 & 0.09 & 0.14 & 0.19 & 0.10 & 0.13 \\
\hline $\mathrm{CaO}$ & 0.23 & 0.78 & 0.91 & 0.40 & 0.18 & 0.18 & 0.24 \\
\hline $\mathrm{Na}_{2} \mathrm{O}$ & 3.02 & 3.33 & 3.54 & 3.85 & 3.67 & 3.26 & 4.06 \\
\hline $\mathrm{K}_{2} \mathrm{O}$ & 5.20 & 4.60 & 4.12 & 4.23 & 3.75 & 4.90 & 4.22 \\
\hline $\mathrm{P}_{2} \mathrm{O}_{5}$ & 0.03 & 0.03 & 0.02 & 0.02 & 0.06 & 0.02 & 0.03 \\
\hline LOI & 0.20 & 0.69 & 0.53 & 0.33 & 0.36 & 0.18 & 0.14 \\
\hline $\mathrm{S}$ & 0.01 & 0.01 & 0.01 & 0.01 & 0.01 & 0.01 & 0.01 \\
\hline Total & 99.87 & 99.82 & 99.88 & 99.88 & 99.88 & 100.26 & 99.99 \\
\hline $\mathrm{Ba}$ & 1487 & 1034 & 1371 & 1285 & 1114 & 1192 & 1344 \\
\hline $\mathrm{Cr}$ & 19 & 19 & 17 & 16 & 14 & 13 & 17 \\
\hline $\mathrm{Cu}$ & 6 & 2 & 6 & 1 & 1 & 1 & 1 \\
\hline $\mathrm{Ga}$ & 17 & 17 & 17 & 19 & 20 & 18 & 18 \\
\hline $\mathrm{Nb}$ & 15 & 14 & 13 & 14 & 16 & 15 & 13 \\
\hline $\mathrm{Ni}$ & 4 & 5 & 3 & 4 & 4 & 4 & 4 \\
\hline $\mathrm{Pb}$ & 24 & 25 & 31 & 21 & 15 & 19 & 15 \\
\hline $\mathrm{Rb}$ & 157 & 140 & 127 & 126 & 124 & 154 & 118 \\
\hline $\mathrm{Sr}$ & 74 & 110 & 119 & 95 & 78 & 80 & 92 \\
\hline Th & 12 & 15 & 17 & 11 & 7 & 9 & 20 \\
\hline V & 6 & 10 & 10 & 16 & 10 & 8 & 18 \\
\hline Y & 61 & 61 & 50 & 48 & 54 & 64 & 56 \\
\hline $\mathrm{Zn}$ & 50 & 67 & 92 & 51 & 85 & 77 & 50 \\
\hline $\mathrm{Zr}$ & 284 & 320 & 264 & 329 & 315 & 321 & 147 \\
\hline $\mathrm{La}$ & 67 & 62 & 75 & 64 & 30 & 47 & 137 \\
\hline $\mathrm{Ce}$ & 118 & 160 & 180 & 137 & 95 & 98 & 289 \\
\hline $\mathrm{Nd}$ & 63 & 59 & 55 & 57 & 33 & 44 & 93 \\
\hline
\end{tabular}

Table 2. Instrument operating conditions and settings.

\begin{tabular}{llll}
\hline ICP-MS & & Laser system & \\
\hline Type & Quad in first zone & Type & ArF excimer \\
Mode & Standard & Wavelength & $193 \mathrm{~nm}$ \\
Scanning regime & Peak jumping & Pulse duration & $<5 \mathrm{~ns}$ \\
RF power & $1400 \mathrm{~W}$ & Energy density & $10.2 \mathrm{~J} / \mathrm{cm}^{2}$ \\
Plasma gas flow rate & $15 \mathrm{l} / \mathrm{min}$ & Output laser energy & $6.2 \mathrm{Mj}$ \\
Aux. gas flow rate & $0.82 \mathrm{l} / \mathrm{min}$ & Focus conditions & At sample surface \\
Neb. gas flow rate & $0.84 \mathrm{l} / \mathrm{min}$ & Repetition rate & $5 \mathrm{~Hz}$ \\
Abl. gas flow rate $(\mathrm{He})$ & $0.92 \mathrm{l} / \mathrm{min}$ & Spot size & $35 \mu \mathrm{m}$ \\
${ }^{202} \mathrm{Hg},{ }^{204} \mathrm{~Pb},{ }^{208} \mathrm{~Pb},{ }^{232} \mathrm{Th}$ & $10 \mathrm{~ms}$ & Cell volume & $30 \mathrm{~cm}^{3}$ \\
${ }^{235} \mathrm{U},{ }^{206} \mathrm{U}$, & & \\
\hline
\end{tabular}




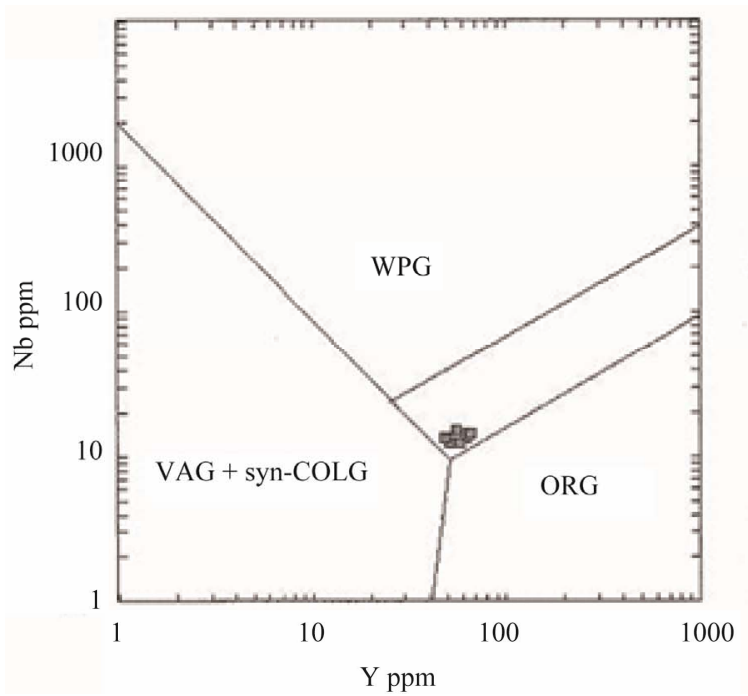

(a)

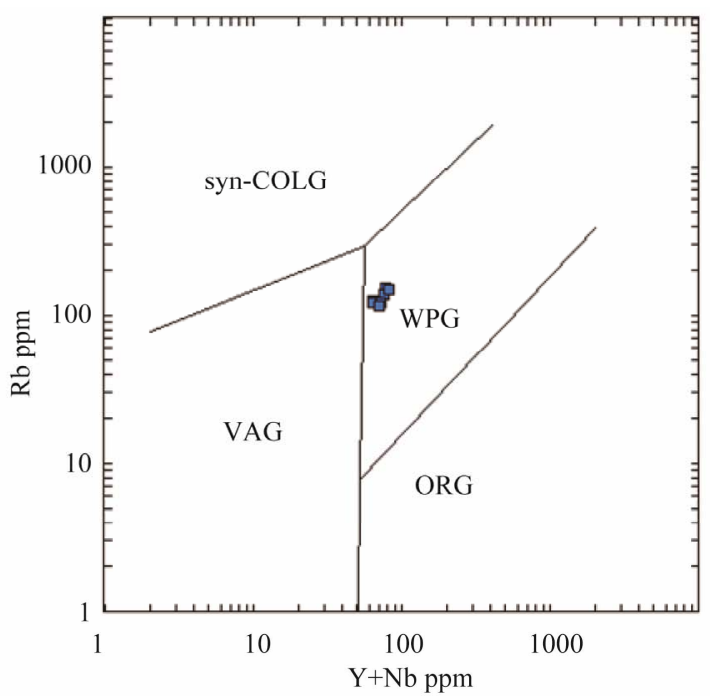

(b)

Figure 5. (a) Tectonic classification of the gneiss after Pearce et al. (1984); (b) Tectonic classification of the gneiss after Pearce et al. (1984).

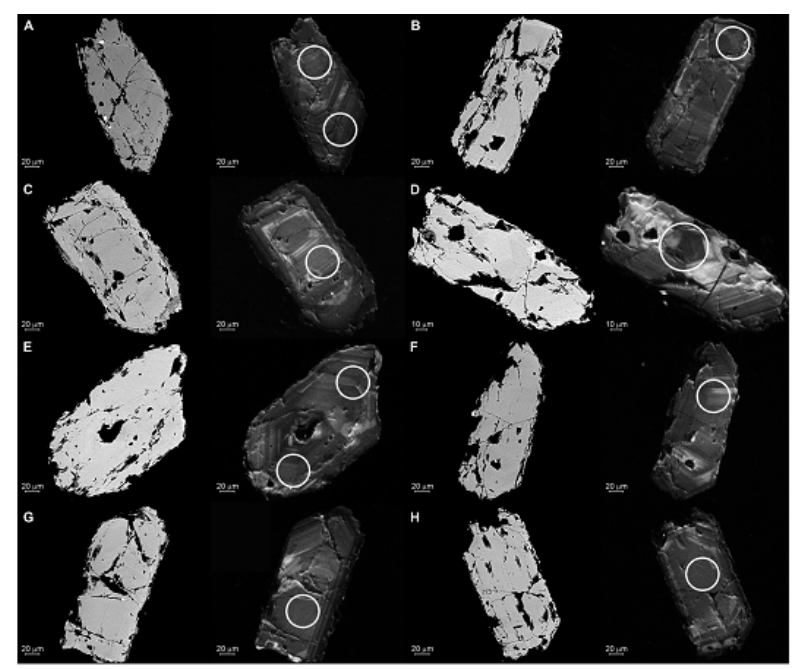

Figure 6. Back-scarrered electron images (left side) and cathodoluminescence images (right side) of the analyzed zircon grains (letter symbols as in Table 3); the ablation points are marked with circles.

tained isotope ratios are presented in Table 3. The concordia diagram and the weighted average ratio of the ${ }^{206} \mathrm{~Pb} /{ }^{238} \mathrm{U}$ age are presented in Figures 7(a) and (b), respectively.

The fifteen analyzed zircon grains give a concordant data cluster age of $2207 \pm 20 \mathrm{Ma}$ (Figure 7(a)) which can be interpreted to be the crystallization age of the granite protolith and therefore the time of emplacement of the granite. The above-mentioned concordant age has no record of the Pan-African imprint and so indicates that inspite of its Paleoproterozoic value and the relatively low level of concordance obtained, this particular isotopic system had remained closed since the Eburnean times.
It has therefore not been affected by the Pan-African tectonothermal reworking.

\section{Discussion}

The age obtained, $2207 \pm 20 \mathrm{Ma}$, for the emplacement/ crystallization of the Jebba leucocratic granitic gneiss which is early Paleoproterozoic is slightly earlier than the time of the Eburnean orogenic cycle in southern Mali, West Africa, which has been established at between 2100 and $2070 \mathrm{Ma}$ [26]. The gneissic Gondo granite in the Paleoproterozoic Bole-Nangodi belt, Ghana associated with Birimian rifting has been dated at $2187 \mathrm{Ma}$ [27] and was emplaced prior to the Eoeburnean collision at $c a$ $2150 \mathrm{Ma}$.

According to [28] ferroan calc-alkali granitoids are more likely to have formed from magmas derived from crustal melting or those that have incorporated large amounts of crustal melt. The geochemical characteristics of the Jebba granitic gneiss as well as its close association with amphibolites similar to icelandites [20] suggest its emplacement in a within-plate, continental, extensional tectonic regime and derivation from a magma that had crustal influence.

The heterogeneous nature of the Pan-African tectonothermal reworking in the Nigerian basement complex whereby Paleoproterozoic rocks have escaped isotopic resetting has been recognized by some workers, especially in southwestern Nigeria [2,3]. Geochronological data particularly $\mathrm{U}-\mathrm{Pb}$ on zircons have documented the occurrence of several Paleoproterozoic orthogneisses in southwestern Nigeria including the Kabba granodioritic gneiss [2], dated $2103 \pm 8 \mathrm{Ma}$.

The Paleoproterozoic was a very important crust- 
Table 3. LA-ICP-MS data of 15 zircon grains (17 ablation points) from the Jebba granitic gneiss.

\begin{tabular}{|c|c|c|c|c|c|c|c|}
\hline Ablation points & $207 / 235$ & r.s.e. [\%], $(2 \sigma)$ & $206 / 238$ & r.s.e. [\%], $(2 \sigma)$ & rho & 206/238 age, [Ma] & r.s.e. $6 / 8$, [Ma] \\
\hline Grain-01 & 7.87024 & 10.3 & 0.39554 & 8.6 & 0.51 & 2168.3 & 186.5 \\
\hline Grain-02 & 7.34559 & 10.4 & 0.38502 & 8.6 & 0.55 & 2127.3 & 182.9 \\
\hline Grain-03-A (up) & 7.70871 & 9.9 & 0.39708 & 8.1 & 0.53 & 2183.8 & 176.9 \\
\hline Grain-03-A (down) & 7.65087 & 9.7 & 0.4035 & 7.7 & 0.5 & 2148.8 & 165.5 \\
\hline Grain-04-B & 8.01039 & 8.9 & 0.40997 & 7.3 & 0.54 & 2180.4 & 159.2 \\
\hline Grain-05-C & 7.98088 & 8.7 & 0.41499 & 7.1 & 0.51 & 2245.3 & 159.4 \\
\hline Grain-06-D & 8.16117 & 8.3 & 0.4181 & 6.7 & 0.51 & 2237.9 & 151.1 \\
\hline Grain-07-E (up) & 7.93274 & 8.1 & 0.39621 & 6.6 & 0.56 & 2131.4 & 140.7 \\
\hline Grain-07-E (down) & 7.83037 & 8.1 & 0.40266 & 6.6 & 0.51 & 2175.9 & 143.6 \\
\hline Grain-08 & 7.99646 & 8.4 & 0.4124 & 6.8 & 0.5 & 2241.2 & 152.6 \\
\hline Grain-09 & 7.68639 & 8.4 & 0.38821 & 6.8 & 0.53 & 2124 & 144.4 \\
\hline Grain-10-F & 7.97556 & 9.4 & 0.39251 & 7.4 & 0.53 & 2163.2 & 161.1 \\
\hline Grain-11 & 7.89206 & 9.9 & 0.39738 & 8.1 & 0.55 & 2153.4 & 174.4 \\
\hline Grain-12-G & 7.69848 & 10.2 & 0.39899 & 8.3 & 0.52 & 2149.7 & 178.4 \\
\hline Grain-13 & 7.81764 & 11.1 & 0.39867 & 9.1 & 0.54 & 2140.9 & 194.8 \\
\hline Grain-14 & 7.61033 & 9.9 & 0.37961 & 7.9 & 0.47 & 2089.5 & 165.1 \\
\hline Grain-15-H & 7.53674 & 9.8 & 0.3893 & 7.6 & 0.56 & 2097.9 & 159.4 \\
\hline
\end{tabular}

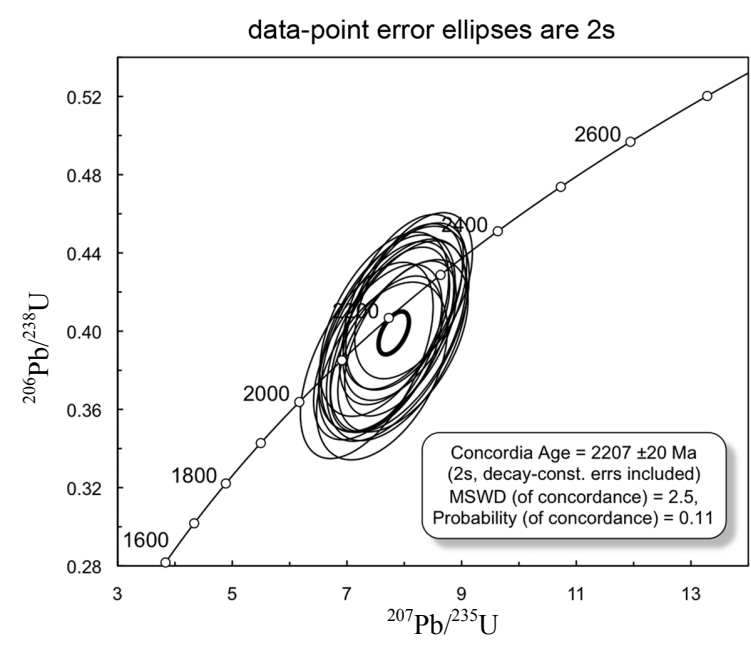

(a)

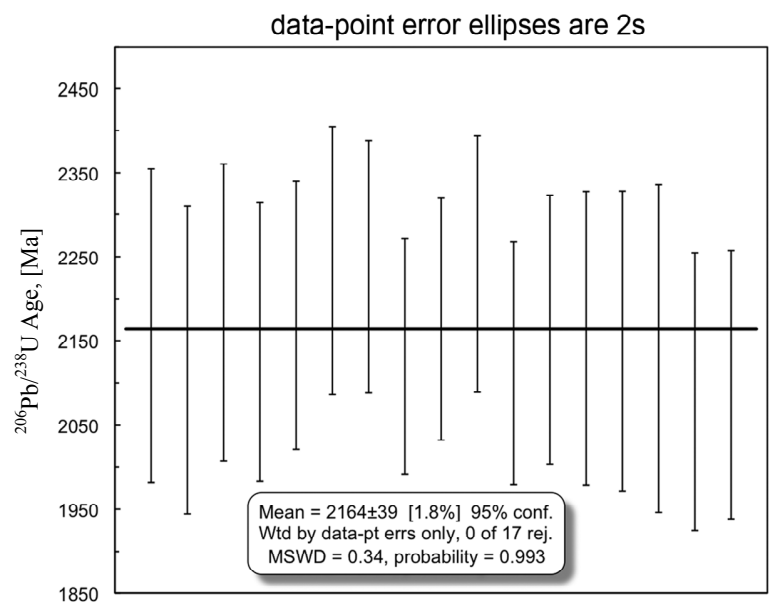

(b)

Figure 7. (a) U-Pb concordia diagram of the analyzed zircons; (b) Weighted average ${ }^{206} \mathrm{~Pb} /{ }^{235} \mathrm{U}$ age of the zircons.

forming period of time marked by long-lived granitic magmatism in Africa and South America [29,30] as similar ages on orthogneisses and granitoids have been documented from the Nigerian basement complex, parts of the West African craton, the Zenaga inlier, Morrocco [31], the Borborema Province [32], Gurupi Belt, Brazil [33], Sao Luis craton, Brazil [34], and the Sao Francisco craton, Brazil [35], among others.

It has been suggested on the basis of geological and geochronological data that the Amazonian, West African, Sao Francisco, Congo cratons as well as the basements of the Araguaia, Borborema, Nigerian and Cameroon prov- inces were part of the Atlantica Supercontinent established at the end of the Trans-Amazonian/Eburnean orogenic cycle at ca $2000 \mathrm{Ma}$ [35].

\section{Conclusions}

In Jebba area, Paleoproterozoic, early Rhyacian, granitoid magmatism was related to crustal extension and rifting prior to the main period of the Eburnean orogenic cycle. Early tectonic fabrics in the Jebba granitic gneiss defined by the strong planar preferred orientation of quartz, the feldspars, muscovite and opaque ores are pro- 
bably the products of Eburnean deformation at mid amphibolite facies of metamorphism. The late tight to open recumbent folds of these early fabrics are probably due to the Neoproterozoic, Pan-African (ca $600 \mathrm{Ma}$ ) orogeny which also involved the emplacement of largely undeformed granitic rocks which intruded the metamorphic rocks in the area.

The Jebba granitic gneiss therefore forms part of the Paleoproterozoic basement that escaped remobilization during the subsequent Neoproterozoic Pan-African orogeny at ca $600 \mathrm{Ma}$ and still retains the imprint of the Paleoproterozoic Eburnean orogeny at ca $2000 \mathrm{Ma}$.

\section{Acknowledgements}

We acknowledge the assistance of Prof. J. A. Winchester and Mr D. Emley with XRF geochemical analysis, L. Macheva for preparation of the zircon grain mounts and $\mathrm{N}$. Issa for assistance during the fieldwork.

\section{REFERENCES}

[1] E, Ferre, G. Gleizeis and R. Caby, "Obliquely Convergent Tectonics and Granite Emplacement in the Trans-Saharan Belt of Eastern Nigeria: A Synthesis," Precambrian Research, Vol. 114, No. 3, 2002, pp. 199-219. doi:10.1016/S0301-9268(01)00226-1

[2] A. E. Annor, "U-Pb Zircon Age for Kabba-Okene Granodiorite Gneiss: Implication for Nigeria's Basement Chronology," Africa Geoscience Reviews, Vol. 2, No. 1, 1995, pp. 101-105.

[3] S. S. Dada, "Proterozoic Evolution of the Nigeria-Borborema Province," In: R. J. Pankhurst, R. A. Trouw, B. B. Brito Neves and M. J. De Wit, Eds., West Gondwana: Pre-Cenozoic Correlations across the South Atlantic Region, Geological Society of London Special Publication, London, 2008, pp. 121-136.

[4] N. K. Grant, "The Geochronology of Precambrian Basement Rocks from Ibadan, Southwestern Nigeria," Earth and Planetary Science Letters, Vol. 10, No. 1, 1970, pp. 28-38. doi:10.1016/0012-821X(70)90061-0

[5] V. M. Oversby, "Lead Isotope Study of Aplites from the Precambrian Rocks near Ibadan Southwestern Nigeria," Earth and Planetary Science Letters, Vol. 27, No. 2, 1975, pp. 177-180. doi:10.1016/0012-821X(75)90027-8

[6] O. van Breemen, R. Pidgeon and P. Bowden, "Age and Isotopic Studies of Pan-African Granites Fromnorthcentral Nigeria," Precambrian Research, 1977, Vol. 4, pp. 301-319.

[7] W. R. Fitches, A. C. Ajibade, I. G. Egbuniwe, R. W. Holt and J. B. Wright, "Late Proterozoic Schist Belts and Plutonism in NW Nigeria," Journal of the Geological Society of London, Vol. 142, No. 2, 1985, pp. 312-337. doi:10.1144/gsjgs.142.2.0319

[8] M. Caen-Vachette and A. C. Umeji, "Geology and Geochronology of Okene Area: Evidence for an Eburnean Orogenic Cycle in South-Central Nigeria," Journal of Af- rican Earth Sciences, Vol. 7, No. 1, 1987, pp. 121-126. doi:10.1016/0899-5362(88)90058-9

[9] M. A. Rahaman, "Recent Advances in the Study of the Basement Complex of Nigeria," In: P. O. Oluyide, W. C. Mbonu, A. E. Ogezi, I. G. Egbuniwe, A. C. Ajibade and A. C. Umeji, Eds., Precambrian Geology of Nigeria, Geological Survey of Nigeria, Kaduna, 1988, pp. 11-41.

[10] A. E. Annor and S. J. Freeth, "Thermotectonic Evolution of the Basement Complex around Okene, Nigeria: With Special Reference to Deformation Mechanism," Precambrian Research, Vol. 28, No. 3-4, 1983, pp. 269-281. doi:10.1016/0301-9268(85)90034-8

[11] A. C. Ajibade and J. B. Wright, "Structural Relationships in the Schist Belts Ofnorthwestern Nigeria," In: P. O. Oluyide, W. C. Mbonu, A. E. Ogezi, I. G. Egbuniwe, A. C. Ajibade and A. C. Umeji, Eds., Precambrian Geology of Nigeria, Geological Survey of Nigeria, Kaduna, 1988, pp. 103-109.

[12] B. N. Ekwueme, "The Geological Evolution of Southeastern Nigeria," University of Calabar Press, Calabar, 1987.

[13] C. T. Okonkwo, "Structural Evolution of Precambrian Basement Rocks of Jebba Area, S. W. Nigeria", Global Journal of Geological Sciences, Vol. 6, 2008, pp. 145152. doi:10.4314/gigs.v6i2.18764

[14] M. A. Rahaman, W. O. Emofurieta and M. Caen-Vachette, "The Potassic Granites of Igbeti Area: Further Evidence of the Polycyclic Evolution of the Pan-African Belt in Southwestern Nigeria," Precambrian Research, Vol. 22, No. 1-2, 1983, pp.75-92. doi:10.1016/0301-9268(83)90059-1

[15] C. T. Okonkwo and J. A. Winchester, "Geochemistry of Granitic Rocks in Jebba Area, Southwestern Nigeria," Journal of Mining and Geology, Vol. 40, No. 2, 2004, pp. 95-100.

[16] K. G. Cox, J. D. Bell and R. J. Pankhurst, "The Interpretation of Igneous Rocks," George Allen and Unwin, London, 1979.

[17] A. Peccerillo and S. R. Taylor, "Geochemistry of Eocene calc-Alkaline Volcanic Rocks from the Kastamonu Area, Northern Turkey," Contributions to Mineralogy and Petrology, Vol. 58, No. 1, 1976, pp. 63-81. doi:10.1007/BF00384745

[18] B. R. Frost, C. G. Barnes, W. J. Collins, R. J. Arculus, D. J. Ellis and C. D. Frost, "A Geochemical Classifycation for Granitic Rocks," Journal of Petrology, Vol. 42, No. 11, 2001. pp. 2033-2048. doi:10.1093/petrology/42.11.2033

[19] J. A. Pearce, N. B. W. Harris and A. G. Tindle, "Trace Element Discrimination Diagrams for the Tectonic Interpretation of Granitic Rocks," Journal of Petrology, Vol. 25, No. 4, 1984, pp. 956-983.

[20] C. T. Okonkwo and J. A. Winchester, "Geochemistry and Geotectonic Setting of Precambrian Amphibolites and Granitic Gneisses in the Jebba Area, Southwestern Nigeria," Journal of Mining and Geology, Vol. 32, No. 1, 1996, pp. 11-18.

[21] F. Corfu, J. M. Hanchar, P. W. O. Hoskin and P. Kinny, 
"Atlas of Zircon Textures," Reviews in Mineralogy and Geochemistry, Vol. 53, 2003, pp. 469-495

[22] S. E. Jackson, N. J. Pearson, W. L. Griffin and E. A. Belousova, "The Application of Laser Ablation-Inductively coupled Plasma-Mass Spectrometry to in Situ U-Pb Zircon Geochronology," Chemical Geology, Vol. 211, No. 1-2, 2004, pp. 47-69. doi:10.1016/j.chemgeo.2004.06.017

[23] J. Slama, J. Kosler, D. J. Condon, J. L. Crowley, A. Gerdes, J. M. Hanchar, M. S. A. Horstwood, G. A. Morris, L. Nasdala, N. Norberg, U. Schaltegger, B. Schoene, M. N. Tubrett and M. J. Whitehouse, "Plesovice Zircon-A New Natural Reference Material for U-Pb and Hf Isotopic Microanalysis," Chemical Geology, Vol. 249, No. 1-2, 2008, pp. 1-35. doi:10.1016/j.chemgeo.2007.11.005

[24] C. Paton, J. Hellstrome, B. Paul, J. Woodhead and J. Hergt, "Iolite: Freeware for the Visualization and Processing of Mass Spectrometer Data," Journal of Analytical Atomic Spectrometry, Vol. 26, 2011, pp. 2508-2518. doi:10.1039/clja10172b

[25] K. R. Ludwig, "Isoplot/Ex Version 3.00: A Geochronological Toolkit for Microsoft Excel," Berkeley Geochronology Center, Berkeley, 2003.

[26] J. P. Liegeois, W. Claessens, D. Camara and J. Klerkx, "Short-Lived Eburnian Orogeny in Southern Mali. Geology, Tectonics, U-Pb and Rb-Sr Geochronology," Precambrian Research, Vol. 50, No. 1-2, 1991, pp. 111-136. doi:10.1016/0301-9268(91)90050-K

[27] G. S. de Kock, H. Theveniaut, P. M. W. Botha and W. Gyapong, "Timing the Structural Events in the Paleoproterozoic Bole-Nangodi Belt Terrane and Adjacent Maluwe Basin, West African Craton, in Central-West Ghana," Journal of African Earth Sciences, Vol. 65, 2012, pp. 1-24. doi:10.1016/j.jafrearsci.2011.11.007

[28] C. D. Frost and B. R. Frost, "On Ferroan (A-type) Granitoids: Their Compositional Variability and Modes of Origin," Journal of Petrology, Vol. 52, No. 1, 2011, pp. 3953. doi:10.1093/petrology/egq070

[29] M. Boher, W. Abouchami, A. Michard, F. Albarede and
N. Arndt, "Crustal Growth in West Africa at 2.1 Ga," Journal of Geophysical Research, Vol. 97, No, B1, 1992, pp. 345-369. doi:10.1029/91JB01640

[30] M. H. B. M. Hollanda, C. J. Archanjo, L. C. Souza, L. Dunyi and R. Armstrong, "Long-Lived Paleoproterozoic Granitic Magmatim in the Serido-Jaguaribe Domain, Borborema Province-NE Brazil," Journal of South American Earth Sciences, Vol. 32, No. 4, 2011, pp. 287-300. doi:10.1016/i.jsames.2011.02.008

[31] N. Ennih and J. P. Liegeois, "The Boundaries of the West African Craton, with Special Reference to the Basement of the Moroccan Metacratonic Anti-Atlas Belt," In: N. Ennih and J. P. Liegeois, Eds., The boundaries of the West African Craton, Geological Society of London, London, 2008, pp. 1-17.

[32] M. H. Arthaud, R. Caby, R. A. Fuck, E. L. Dantas and C. V. Parente, "Geology of the Northern Borborema Province, NE Brazil and Its Correlation with Nigeria, NW Africa," In: R. J. Pankhurst, R. A. Trouw, B. B. Brito Neves, and M. J. De Wit, Eds., West Gondwana: Pre-Cenozoic Correlations across the South Atlantic Region, Geological Society of London, London, 2008, pp. 49-67.

[33] E. L. Klein and C. A. V. Moura, "Sao Luis Craton and Gurupi Belt (Brazil): Possible Links with the West African Craton and Surrounding Pan-African Belts," In: R. J. Pankhurst, R. A. Trouw, B. B. Brito Neves and M. J. De Wit, Eds., West Gondwana: Pre-Cenozoic Correlations across the South Atlantic Region, Geological Society of London, London, 2008, pp. 137-151.

[34] E. L. Klein, C. A. V. Moura, R. S. Krymsky and W. L. Griffin, "The Gurupi Belt, Northern Brazil: Lithostratigraphy, Geochronology, and Geodynamic Evolution," Precambrian Research, Vol. 141, No. 3-4, 2005, pp. 83105. doi:10.1016/j.precamres.2005.08.003

[35] S. P. Neves, "Proterozoic History of the Borborema Province (NE Brazil): Correlations with Neighboring Cratons and Pan-African Belts and Implications for the Evolution of Western Gondwana," Tectonics, Vol. 22, No. 4, 2003, p. 1031, doi:10.1029/2001TC001352 